\title{
Edukacja między filozofią i teologią. XI Polski Zjazd Filozoficzny w Lublinie z perspektywy historii myśli pedagogicznej
}

Rok 2019 był dla Lublina - miasta leżącego na styku kultur Wschodu i Zachodu niezwykle uroczysty. Stolica województwa lubelskiego świętowała 450-lecie zawarcia Unii Lubelskiej - symbolu pokojowej i demokratycznej integracji dwóch krajów, zróżnicowanych religijnie i etnicznie. Unia polsko-litewska podpisana w Lublinie w 1569 r. stała się wydarzeniem powołującym do życia Rzeczpospolitą Obojga Narodów i tym samym zapewniła miastu udział w dziejach państwowości polskiej.

W tej podniosłej atmosferze odbywały się również obrady XI Polskiego Zjazdu Filozoficznego, który stanowił kolejne wydarzenie przyczyniające się do wyjątkowości lubelskiego roku 2019. Głównym organizatorem i gospodarzem Zjazdu był Wydział Filozofii Katolickiego Uniwersytetu Lubelskiego Jana Pawła II, zaś współorganizatorami Komitet Nauk Filozoficznych PAN oraz Polskie Towarzystwo Filozoficzne. Uczestnicy Zjazdu mieli do wyboru 20 sekcji tematycznych, w ramach których toczyły się obrady. Podział na sekcje odzwierciedlał poszczególne dziedziny filozofii i jednocześnie w sposób przejrzysty prezentował przegląd aktualnych badań danej subdyscypliny filozoficznej. W zakres programu Polskiego Zjazdu Filozoficznego wchodziły również: wykłady plenarne, panele dyskusyjne oraz sympozja specjalne. Zapewne specyfika religijna miejsca obrad sprawiła, że w porównaniu z programem X Polskiego Zjazdu Filozoficznego, który odbywał się w Poznaniu, w Lublinie zabrakło Sekcji Filozofii Feministycznej i gender studies, Sekcji Ekofilozofii, Sekcji Filozofii Wschodu, a w nazwie Sekcji Historii Filozofii Starożytnej i Średniowiecznej został wyeliminowany przymiotnik ,bizantyjski”.

Analizując programu Zjazdu od strony pedagogicznej, można przyjąć, że jako najważniejsza wyłoniła się Sekcja Dydaktyki Filozofii. Jej tematyka dotyczyła nie tylko nauczania filozofii na poszczególnych stopniach edukacji, w tym uczelni wyższej, ale również popularyzowania jej poza kształceniem formalnym. Uwagę historyka wychowania 
przyciągało wystąpienie Wojciecha Rechlewicza pt. Czy Kazimierza Twardowskiego model ksztatcenia filozoficznego jest aktualny? Aby odpowiedzieć na powyższe pytanie, autor w części pierwszej referatu przedstawił poglądy Twardowskiego dotyczące kształcenia filozoficznego na poziomie średnim i uniwersyteckim, natomiast później odniósł je do realiów współczesnej edukacji.

Z punktu widzenia historii wychowania, w czasie Zjazdu na pierwszy plan wysunęli się prelegenci, którzy swoje wyniki badań zaprezentowali w ramach Sekcji Historii Filozofii Starożytnej i Średniowiecznej oraz Sekcji Historii Filozofii Polskiej.

Referat ks. prof. Andrzeja Uciechy pt. Teologiczne aspekty zbawczej pedagogii w ujeсіи Ireneusza z Lyonu, zakwalifikowany do programu Sekcji Historii Filozofii Starożytnej i Średniowiecznej, explicite przystawał do historii myśli pedagogicznej. Punktem wyjścia badań autora było podkreślenie, że prawda o wcieleniu Syna Bożego (misterium „Deus-Homo") stanowi centrum teologii biskupa z Lyonu i to z niej wypływają poważne implikacje pedagogiczne w odniesieniu do człowieka. Motywem przewodnim Ireneuszowej pedagogii była relacja między Bogiem a człowiekiem, a zatem jej głównych założeń należy poszukiwać na płaszczyźnie antropologicznej. Sięgając do postaci apostoła Pawła, Ireneusz porównał sytuację człowieka względem Boga do kondycji noworodka, który może otrzymać od matki pokarm doskonały, lecz nie jest w stanie go przyjąć. Mimo że człowiek otrzymał w akcie stworzenia obraz i podobieństwo do Stwórcy, to jego infantylna natura świadczy o tym, że do pełni podobieństwa musi jeszcze dorosnąć i doskonalić się. Innymi słowy, Adam ${ }^{1}$, aby osiągnąć pełną dojrzałość musi się rozwijać, przejść ze stanu dziecięctwa do stanu dorosłości. Powyższy cel pedagogii odnosi się do każdego człowieka, który powinien wzrastać i upodobniać się do Stwórcy poprzez wysiłek i twórczość. Na podstawie badań ks. prof. Uciechy można stwierdzić, że „przyzwyczajenie się" Boga do człowieka i człowieka do Boga stanowi główną kategorię zbawczej pedagogii w ujęciu Ireneusza z Lyonu. Owo wzajemne „przyzwyczajanie się” potrzebuje czasu, by człowiek progresywnie mógł przyjąć Boską obecność. Innymi słowy, celem pedagogii Ireneusza, podobnie jak apostoła Pawła, jest uformowanie „człowieka doskonałego".

Wystąpienie ks. prof. Uciechy ukazało, jak często obraz dziecka funkcjonuje w obrębie teologii. Odwołując się do tego wyobrażenia, Ireneusz z Lyonu w prosty sposób przybliżył trudną relację pomiędzy Bogiem a człowiekiem na gruncie swojej myśli. W tym aspekcie zetknięcie się teologii i pedagogiki jest wręcz naturalne. Podobnej harmonii próżno szukać w filozofii wychowania wyprowadzonej przykładowo z myśli Martina Heideggera. W zderzeniu z pedagogią Ireneusza jawi się ona jako sztuczny twór i nie przemawia do czytelnika tak plastycznie.

1 „Czytając teksty Ireneusza, odnosi się wrażenie, że pierwszy Adam apologety, to ktoś więcej niż pierwszy człowiek stworzony przez Boga. Adam Ireneusza to niejako idea gatunku ludzkiego, która następnie zostaje skażona przez grzech ludzkości, aby zostać odnowioną dzięki zbawczej aktywności Logosu”, R.M. Leszczyński, Starożytna koncepcja Logosu i jej wplyw na myśl wczesnego chrześcijaństwa, Wydawnictwo Naukowe Semper, Warszawa 2003, s. 272. 
W badania ks. prof. Uciecha skoncentrował się na wczesnym etapie rozwoju teologii chrześcijańskiej, zwanym okresem Ojców Apostolskich i apologetów (Ireneusz z Lyonu bezsprzecznie był apologetą). Następny referat, autorstwa Rafała Marcina Leszczyńskiego, dotyczył już pierwszego systemu teologii chrześcijańskiej, którym była myśl Orygenesa. Badania nad aleksandryjczykiem zajmują ważne miejsce w dorobku naukowym Leszczyńskiego ${ }^{2}$. Autor tym razem skoncentrował się na wymiarze pedagogicznym działalności i spuścizny chrześcijańskiego myśliciela, co odzwierciedlił tytuł jego wystąpienia: Metoda egzegetyczna Orygenesa a szkoła katechetyczna w Aleksandrii. Prelegent wykazał dobitnie, że cały proces formowania chrześcijanina w aleksandryjskiej szkole katechetycznej wypływał bezpośrednio z teologii Orygenesa, a konkretnie z jego metody egzegetycznej zwanej alegorezą. Alegoryczny sposób interpretacji świętych tekstów, przejęty przez chrześcijan od stoików, stanowił dla filozofa klucz do odczytania ukrytego znaczenia teologii starotestamentalnej, które - jego zdaniem - zrozumieć mogą tylko zaawansowani duchowo wyznawcy Chrystusa. Stąd biegłość w posługiwaniu się alegoryczną metodą egzegetyczną stanowiła ukoronowanie edukacji w szkole aleksandryjskiej. Aby zbliżyć się do poziomu warsztatu egzegetycznego Mistrza Orygenesa, młody adept musiał przejść długą i żmudną drogę, wyznaczoną przez kolejne etapy wtajemniczenia w kerygmat kościelny. Poszczególne stopnie poznania ucznia odpowiadały trzem poziomom sensu tekstów biblijnych, które - zdaniem Orygenesa - zawierają się w Piśmie Świętym. Na pierwszym poziomie wtajemniczenia znajdowali się wychowankowie, którzy potrafili odczytać dosłowny (cielesny) sens tekstu biblijnego, natomiast wyżej uczniowie zgłębiający moralne (psychiczne) znaczenie Biblii. Ostatni stopień poznania był równoznaczny z umiejętnością posługiwania się przez adeptów alegoryczną metodą egzegetyczną. Zatem funkcjonowanie i organizacja procesu nauczania w szkole katechetycznej prowadzonej przez Orygenesa stanowiła odzwierciedlenie jego założeń na gruncie egzegezy Pisma Świętego. Należy podkreślić, że powyższe stopnie inicjacji chrześcijańskiej chronione były przez disciplina arcani, co zdaniem Leszczyńskiego upodobniło chrześcijaństwo Orygenesa do religii misteryjnych.

Ostatni referat podejmujący problematykę pedagogiczną w tej sesji wygłosiła mgr Agnieszka Teresa Tys. Jej badania dotyczyły fenomenu XVI-wiecznego gimnazjum w Pińczowie, które formowało młodzież szlachecką w duchu Reformacji helweckiej. Przywołanie słynnych badań Stanisława Kota stanowiło punkt wyjścia referatu, albowiem to dzięki nim na kartach historii wychowania zostały zapisane pedagogiczne dokonania ewangelicko-reformowanych teologów, a założona przez nich szkoła stanowiła cenny wkład w kulturę polską. W artykule Pierwsza szkoła protestancka w Polsce. Z historii wpływów francuskich na kulturę polska, opublikowanym na łamach pierwszego numeru „Reformacji w Polsce” (1921), S. Kot zerwał z próbami dyskredytowania jej

\footnotetext{
2 Zob. R.M. Leszczyński, Logos w relacji do Boga i stworzenia w nauczaniu Orygenesa. Studium źródel, „Rocznik Teologiczny” 2005, nr 57, z. 1-2, s. 57-85; idem, Disciplina arcani w dziełach Orygenesa, w: Disciplina arcani w chrześcijaństwie, red. W. Gajewski, B. Górka, Wydawnictwo WAM, Kraków 2015, s. 103-124; idem, Neoplatoński Bóg Orygenesa, „Przegląd Filozoficzny - Nowa Seria” 2016, nr 2, s. 415-423.
} 
znaczenia na gruncie polskim, ukazując ją jako pierwsze miejsce zorganizowanego nauczania, które rozprzestrzeniło myśl renesansową w obrębie kultury I Rzeczypospolitej. Do czasów współczesnych wspomniane badania polskiego historyka kultury nie straciły nic ze swej aktualności i innowacyjności. Można je co najwyżej uzupełniać, co uczynił zresztą jego uczeń Henryk Barycz.

A.T. Tys dokonała analizy pińczowskiego fenomenu wychowawczego w perspektywie filozoficznej i teologicznej, co odzwierciedlał tytuł jej wystąpienia: Humanitas Cycerona a pińczowski projekt wychowawczy. Pierwszy plan badań został zdominowany przez poszukiwania obecności myśli starożytnej w programie nauczania Sarmackich Aten (jak zwano powszechnie szkołę w Pińczowie), ożywionej przez klimat renesansu, a konkretnie humanitas Cycerona. Druga płaszczyzna referatu dotyczyła analizy charakteru wyznaniowego szkoły, czego konsekwencją była próba rekonstrukcji humanitas teologów ewangelicko-reformowanych jako tworu powstałego z połączenia myśli Cycerona i założeń Reformacji helweckiej ${ }^{3}$.

Kolejny referat, wygłoszony przez R.M. Leszczyńskiego w ramach Sekcji Historii Filozofii Polskiej, zachował łączność z kwestiami badawczymi podjętymi przez A.T. Tys, odsłaniając kolejny obszar kultury I Rzeczypospolitej przeobrażony pod wpływem ewangelicyzmu reformowanego, którym była literatura polska, a konkretnie twórczość Mikołaj Reja. Patrząc całościowo na cykl badań Leszczyńskiego poświęcony myśli Nagłowiczanina $^{4}$, można zaobserwować proces transformowania kultury polskiej przez Reformację helwecką. Na XI Polskim Zjeździe Filozoficznym autor przedstawił swoje najnowsze badania w referacie pt. Filozofia wychowania Mikolaja Reja $w$ „Żywocie czlowieka poczciwego". Leszczyński dokonał w nim jednocześnie rewizji badań poświęconych Nagłowiczaninowi na gruncie historii wychowania, jak również przedstawił swoje nowe i oryginalne podejście do Ojca literatury polskiej. Aby zrozumieć wielowymiarowość badań Leszczyńskiego niezbędne jest wniknięcie do jego warsztatu naukowego. Interdyscyplinarne badania naukowca z Chrześcijańskiej Akademii Teologicznej w Warszawie (dalej: ChAT) zamykają się z jednej strony w perspektywie teologii ewangelicko-reformowanej, a z drugiej w filozofii antycznej. Zastosowanie takiej struktury badawczej umożliwia odpowiedź na pytanie, w jakiej mierze Żywot człowieka poczciwego inspirowany jest teologią ewangelicko-reformowaną, a w jakiej mierze filozofią antyczną. Ponadto wskazuje, z jakich założeń wypływa Rejowe pojęcie wychowania, usytuowane pomiędzy tymi dyscyplinami.

\footnotetext{
3 Punktem odniesienia były w tym zakresie badania R.M. Leszczyńskiego zaprezentowane w pracy Cycerońskie watki $w$ Institutio Christianae religionis Jana Kalwina, w: R.M. Leszczyński, Jan Kalwin. Studia nad myśla Reformatora, „Jednota. Pismo religijno-społeczne”, Warszawa 2017, s. 29-61.

4 Zob. R.M. Leszczyński, Wychowanie religijne a wychowanie moralne $w$,Żywocie człowieka poczciwego” Mikołaja Reja, „Łódzkie Studia Teologiczne” 2016, nr 4, s. 103-114; idem, Filozoficzne aspekty koncepcji wychowania dzieci i młodzieży w „Żywocie człowieka poczciwego” Mikołaja Reja, „Kwartalnik Pedagogiczny", 2018, nr 1, s. 24-47; idem, Filozoficzne aspekty refleksji parenetyczno-wychowawczej w drugiej księdze , ¿̇ywota człowieka poczciwego” Mikołaja Reja, „Rocznik Teologiczny” 2019, nr 61, z. 3, s. 541-563.
} 
Wnikliwy słuchacz referatu teologa z ChAT zauważył również, że była w nim obecna perspektywa historyczna, kulturoznawcza oraz literaturoznawcza. Holistyczne spojrzenie na twórczość Mikołaja Reja w Żywocie człowieka poczciwego pozwoliło Leszczyńskiemu ukazać ojca literatury polskiej nie tylko jako filozofa wychowania i moralistę, lecz również jako teologa naturalnego.

Kolejne wyniki badań, które znakomicie wpisują się w obszar historii myśli pedagogicznej, przedstawił Rafał Charzyński w referacie pt. Podstawy polskiej pedagogiki. Całe wystąpienie prelegenta zamknęło się w poszukiwaniu odpowiedzi na pytania: w czym wyraża się specyfika polskiej filozofii wychowania oraz co stanowi wspólny fundament polskiej pedagogiki. Obszarem, w którym autor poszukiwał odpowiedzi na powyższe pytania, były badania Wiktora Wąsika nad dziejami polskiej filozofii wychowania. Zdaniem Wąsika punktem wyjścia polskiej refleksji o wychowaniu była twórczość arystotelika Sebastiana Petrycego z Pilzna, nawiązująca do myśli renesansu. W epoce oświecenia polską filozofię wychowania kontynuowali współtwórcy Komisji Edukacji Narodowej, zaś romantyzm był zdominowany przez filozofię wychowania w ujęciu Bronisława Ferdynanda Trentowskiego.

Wszystkie przedstawione badania, z wyjątkiem referatu R. Charzyńskiego, który był w gruncie rzeczy poszukiwaniem syntezy polskiej pedagogiki, dotyczyły wychowania chrześcijanina. Na ich przykładzie można zobaczyć, jak zróżnicowana była i jest myśl chrześcijańska, dzięki włączeniu w jej obręb różnych nurtów filozoficznych. Na gruncie pedagogicznym zaowocowało to rozmaitością modeli formacji młodych chrześcijan. W przedstawionych powyżej badaniach wyraźnie widać, że ideał chrześcijanina w ujęciu Orygenesa to biegły egzegeta, zaś celem wychowania w pedagogii Ireneusza było dążenie do doskonałości, której wzór to Stwórca. Z kolei Reformacja helwecka zrodziła zupełnie nowy wymiar kształcenia i wychowania młodego chrześcijanina, czego przykład stanowił program gimnazjum w Pińczowie oraz filozofia wychowania Mikołaja Reja.

Przedstawiony powyżej pluralizm chrześcijańskich modeli wychowawczych automatycznie zakłada odmienność antropologii, na podstawie których zostały one ukonstytuowane, dzięki czemu można łatwo obalić stwierdzenie, że pedagogika chrześcijańska opiera się niemal w całości na antropologii tomistycznej ${ }^{5}$. W przypadku przytoczonych badań żadne ujęcie wychowania chrześcijańskiego nie wypływało z tomistycznej koncepcji człowieka. Jeżeli zaś chodzi o współczesną myśl chrześcijańską, to nawet w obrębie filozofii rzymskokatolickiej, której oficjalną wykładnią jest oczywiście neotomizm, współegzystują różne koncepcje człowieka. Jako przykład posłużyć tu może francuski personalizm w ujęciu Emmanuela Mouniera oraz Pierre'a T. de Chardina, zaś na gruncie polskim filozofia Józefa Tischnera, która zrodziła się z buntu przeciwko chrześcijaństwu tomistycznemu.

${ }^{5}$ Por. P. Sosnowska, Arendt i Heidegger. Pedagogiczna obietnica filozofii, Universitas, Kraków 2015, s. 312 . 
Jak wygląda filozofia wychowania, której bazą nie jest antropologia tomistyczna, ukazują zarysowane powyżej badania nad wychowaniem ewangelicko-reformowanym R.M. Leszczyńskiego i A.T. Tys. Należy podkreślić, że wspomniana odmiana wychowania ewangelickiego stanowi słabo eksplorowany obszar humanistyki polskiej. Jedną z przyczyn takiej sytuacji jest częste utożsamianie w naszym kraju przymiotnika „ewangelicki” z ewangelicyzmem augsburskim (luteranizmem), co wręcz eliminuje obecność wychowania ewangelicko-reformowanego w dyskursie naukowym, nie mówiąc już o innych denominacjach protestanckich, takich jak baptyści, metodyści i inni. Autorzy w swoich referatach świadomie rezygnują z używania pejoratywnej formy „kalwin”, zakorzenionej na gruncie humanistyki polskiej, na rzecz formy prawidłowej, jaką jest „ewangelik reformowany”. Ponadto jednym z walorów cyklu badań R.M. Leszczyńskiego nad twórczością Mikołaja Reja polega na łączeniu w sobie jednocześnie oglądu teologa, filozofa i historyka. Takiego podejścia badawczego brakuje opracowaniom Ł. Kurdybachy, S. Kota, S. Sztobryna i in. Trafnie sytuację podsumowuje Katarzyna Meller, według której „,brak na gruncie polskim opracowań interdyscyplinarnych, scalających kompetentny ogląd teologa i historyka" ", „o pisarzach - teologach wypowiada się jednostronnie literaturoznawstwo, bez wsparcia teologii historycznej"”.

Badania autorstwa R.M. Leszczyńskiego i A.T. Tys zaprzeczają również tezie, że Reformacja była historycznym nieszczęściem, że zamiast „naprawić Kościół i społeczności ludzkie, doprowadziła w rzeczywistości do krwawych wojen, które z ideałami humanizmu, rozumianymi jako «odrodzenie świata i człowieka», nie miały zgoła nic wspólnego"8. Można oczywiście opisywać wiek XVII w ten sposób. Pytanie tylko, z jakiej jest to czynione perspektywy? Czy jest ona obiektywna naukowo? Zupełnie inny obraz Reformacji przedstawiają prace autorów zgromadzone w książce pt. Dziedzictwo kulturowe Reformacji w perspektywie polskiej $i$ europejskiej pod redakcją Krzysztofa Pilarczyka. Tutaj nikt nie sprowadzał dziedzictwa Reformacji do krwawych wojen i zaprzepaszczenia przez nią ideałów humanizmu.

Jeśli według Wiktora Wąsika, którego badania przywołuje R. Charzyński we wspomnianym wyżej referacie, podstaw polskiej pedagogiki należy szukać w twórczości arystotelika Petrycego z Pilzna, to na bazie przytoczonych powyżej badań powinno się również dopatrywać ich na niwie refleksji wychowawczej ewangelików-reformowanych w spuściźnie Mikołaja Reja i pińczowskim projekcie wychowawczym autorstwa Piotra Statoriusa, Grzegorza Orszaka i Jana Thenauda.

${ }^{6} \mathrm{~K}$. Meller, Luterańskie novum $w$ kulturze polskiej XVI w. Wprowadzenie do tomu, w: Luteranizm w kulturze Pierwszej Rzeczypospolitej, t. VIII, red. K. Meller, Wydawnictwa Uniwersytetu Warszawskiego, Warszawa 2017, s. 18-19. Mimo że autorka odnosi swoje stwierdzenia do stanu badań nad luteranizmem w kulturze polskiej XVI w., to jej oceny można również odnieść do innych dziedzin humanistycznych, a także do badań na gruncie filozofii czy historii wychowania.

7 Ibidem.

${ }^{8}$ A. Fijałkowski, Tradycja i nowatorstwo $w$ „, Orbis sensualium pictus” Jana Amosa Komeńskiego, Wydawnictwa Uniwersytetu Warszawskiego, Warszawa 2012, s. 177. 
Na pewno udział w Zjeździe Filozoficznym był interesujący poznawczo, albowiem można było spojrzeć na zagadnienia edukacyjne z różnych perspektyw badawczych. Jak widać powyżej, na przykładzie wybranych badań, w których pojęcie wychowania zajmowało główne miejsce, można rozwijać własną refleksję nie tylko w kierunku przeszłości, lecz także przyszłości oraz polemizować ze współczesnymi badaniami na gruncie historii i filozofii wychowania.

\section{Bibliografia}

Fijałkowski A., Tradycja i nowatorstwo w „Orbis sensualium pictus” Jana Amosa Komeńskiego, Warszawa 2012.

Leszczyński R.M, Cycerońskie wątki w Institutio Christianae religionis Jana Kalwina, w: idem, Jan Kalwin. Studia nad myśla Reformatora „Jednota. Pismo religijno-społeczne” 2017, s. 29-61.

Leszczyński R.M, Disciplina arcani $w$ dziełach Orygenesa, w: Disciplina arcani $w$ chrześcijaństwie, red. W. Gajewski, B. Górka, Kraków 2015, s. 103-124.

Leszczyński R.M, Logos w relacji do Boga i stworzenia w nauczaniu Orygenesa. Studium źródet, „Rocznik Teologiczny” 2005, nr 57, z. 1-2, s. 57-85.

Leszczyński R.M, Neoplatoński Bóg Orygenesa, „Przegląd Filozoficzny - Nowa Seria” 2016, nr 2, s. $415-423$.

Leszczyński R.M, Starożytna koncepcja Logosu i jej wpływ na myśl wczesnego chrześcijaństwa, Warszawa 2003.

Leszczyński R.M, Wychowanie religijne a wychowanie moralne $w$ „Żywocie człowieka poczciwego” Mikołaja Reja, „Łódzkie Studia Teologiczne” 2016, nr 4, s. 103-114

Leszczyński R.M., Filozoficzne aspekty koncepcji wychowania dzieci i młodzieży w „Żywocie człowieka poczciwego” Mikołaja Reja, „Kwartalnik Pedagogiczny” 2018, nr 1, s. 24-47.

Leszczyński R.M., Filozoficzne aspekty refleksji parenetyczno-wychowawczej $w$ drugiej księdze „Żywota czlowieka poczciwego” Mikołaja Reja, „Rocznik Teologiczny” 2019, nr 61, z. 3, s. 541-563.

Meller K., Luterańskie novum w kulturze polskiej XVI w. Wprowadzenie do tomu, w: Luteranizm w kulturze Pierwszej Rzeczypospolitej, t. 8, red. K. Meller, Warszawa 2017.

Sosnowska P., Arendt i Heidegger. Pedagogiczna obietnica filozofii, Kraków 2015. 